\title{
Long-term grass yields following chemical control of honey mesquite
}

\author{
R.J. ANSLEY, W.E. PINCHAK, W.R. TEAGUE, B.A. KRAMP, D.L. JONES, AND P.W. JACOBY
}

Authors are Associate Professor (r-ansley@tamu.edu), Associate Professor, Professor, Research Associate, and Research Technician, Texas Agricultural Experiment Station, Vernon, Tex., and Associate Dean, College of Agriculture and Home Economics, Washington State Univ., Pullman, Wash.

\section{Abstract}

Long-term herbaceous response data following herbicidal treatment of honey mesquite (Prosopis glandulosa Torr.) are needed to develop more accurate projections regarding economic feasibility of these treatments and to model ecological interactions between woody and herbaceous plants in rangeland systems. Our objective was to measure herbaceous yield and mesquite regrowth 10 or 20 years after mesquite was aerially sprayed with either mesquite top-killing or root-killing herbicides. Treatments evaluated included mesquite top-killing herbicides at 10-12 years (T10) and 19-21 years (T20) post-treatment, mesquite root-killing herbicides at $10-12$ years $(R 10)$ and $19-21$ years (R20) post-treatment, and an untreated control where mesquite were $>\mathbf{3 0}$ years old $(\mathbf{C 3 0})$. Treatments were applied in the late 1970 's or late 1980 's. Grass yields, measured annually from 1998 through 2000 , were quantified within patches of 3 perennial grass functional groups: cool-season mid-grasses, warm-season mid-grasses, or warm-season short-grasses. Coolseason annual grass yields were also quantified within these perennial grass patches. By 1998, mesquite canopy cover was 55, $47,36,24$, and $12 \%$ in C30, T20, T10, R20, and R10 treatments, respectively. Warm-season mid-grass yields were most sensitive to differences in mesquite cover in all 3 years and declined sharply when mesquite cover exceeded $30 \%$. Cool-season midgrass yields declined slightly with increasing mesquite cover. Warm-season short-grass and cool-season annual grass yields were not related to mesquite cover, except in 2000 when warmseason short-grass yield beneath mesquite canopies increased with increasing mesquite cover. Results suggest that herbicide treatment life (defined by increased perennial grass yield in response to mesquite treatments) was at least 20 years for the root-killing herbicide, but no longer than $\mathbf{1 0}$ years for the topkilling herbicide.

Key Words: brush management, Buchloe dactyloides, clopyralid, herbicides, Prosopis glandulosa, Nasella leucotricha, triclopyr, woody plant encroachment

Research was funded by grants from the E. Paul and Helen Buck Waggoner Foundation, Vernon, Tex., and Dow AgroSciences, Indianapolis, Ind. We thank the W.T. Waggoner Ranch for providing land area for the study. Tim Tunnell, Matt Angerer, Stuart McMullen, Ken Caldwell, Neil Teague and David Echols assisted in data collection. We appreciate the assistance of Hardcastle Ag-Air, Vernon during herbicide application. Don Robinson and Wylie Harris reviewed earlier drafts of the manuscript.

Manuscript accepted 14 Apr. 2003.

\section{Resumen}

Se necesitan datos a largo plazo de la respuesta de la vegetación herbácea después del tratar con herbicida al "Honey mezquite" (Prosopis glandulosa Torr.) para desarrollar proyecciones más certeras respecto a la factibilidad económica de estos tratamientos y modelar las interacciones ecológicas entre las plantas leñosas y herbáceas de los sistemas de pastizal.. Nuestro objetivo fue medir el rendimiento del estrato herbáceo y el rebrote de "Mezquite" 10 o 20 años después de que fue asperjado vía aérea con herbicidas para matar la parte aérea de la planta o con herbicidas para matarlos de raíz. Los tratamientos evaluados, incluyeron herbicidas de muerte aérea del "Mezquite"1012 años (T10) y 19-21 años (T20) después de aplicados, herbicidas de muerte de raíz del "Mezquite" 10-12 años (R10) y de 1921 años (R20) después de aplicados y un tratamiento control sin aplicación en el que los "Mezquites eran de más de 30 años de edad (C30). Los tratamientos fueron aplicados a fines de los años 70 's o a fines de los 80 's. Los rendimientos de zacate, medidos

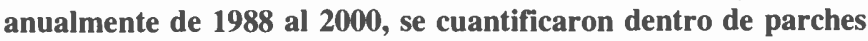
de 3 grupos funcionales de zacates perennes, zacates medianos de estación fría, zacates medianos de estación caliente o zacates cortos de estación caliente. Los rendimientos de zacates anuales de estación fría también se cuantificaron dentro de estos parches de vegetación Para 1998, la cobertura de copa del "Mezquite" era $55,47,36,24$, y $12 \%$ en los tratamientos C30, T20, T10, R20, y $\mathrm{R} 10$ respectivamente. Los rendimientos de los zacates medianos de estación caliente fueron los más sensibles a la diferencia de cobertura de "Mezquite", en los tres años disminuyó abruptamente cuando la cobertura de mezquite excedió el $30 \%$. Los rendimientos de zacates medianos de estación fría disminuyeron ligeramente al incrementar la cobertura de mezquite. Los rendimientos de los zacates cortos de estación caliente y los anuales de estación fría no estuvieron correlacionados con la cobertura de mezquite, excepto en el año 2000, cuando el rendimiento de los zacates cortos de estación caliente bajo las copas de "Mezquites" se incrementó con el aumento de la cobertura de mezquite. Los resultados sugieren que la vida del tratamiento del herbicida (definido por el incremento del rendimiento de zacates perennes en respuesta a los tratamientos del "Mezquite") fue al menos 20 años para los herbicidas de muerte radical, pero no más de $\mathbf{1 0}$ años para los herbicidas que producen muerte aérea.

Long-term herbage yield data following herbicidal treatment of honey mesquite (Prosopis glandulosa Torr.) are needed to develop more accurate projections regarding economic feasibility of these treatments (vanTassell and Conner 1986, Teague et al. 
2001). Moreover, few herbage response or economic studies have been performed on mesquite treated with clopyralid $(3,6-$ dichloro-2-pyridinecarboxylic acid, monoethanolamine salt), even though this chemical, made commercially available for mesquite control in 1987, produces consistently greater mesquite mortality (root-kill) than any chemical that preceded it (Jacoby et al. 1981, Ansley et al. 2003).

A currently-used treatment to reduce extensive infestations of mature honey mesquite is aerial application of a 1:1 mixture of clopyralid and triclopyr $(3,5,6-$ trichloro-2-pyridinyloxyacetic acid, butyoxyethyl ester), usually at $0.28 \mathrm{~kg} \mathrm{ha}^{-1}$ active ingredient each (McGinty et al. 2000). This treatment achieves at least $50 \%$ root-kill and $>90 \%$ canopy reduction (Bovey and Whisenant 1991). A less expensive treatment of triclopyr at $0.56 \mathrm{~kg}$ $\mathrm{ha}^{-1}$ suppresses mesquite by killing above ground portions of the plant (top-kill), but most treated plants resprout from subterranean meristem near the root crown and grow into multi-stemmed plants (Jacoby and Meadors 1983). Effects of triclopyr are similar to those of $2,4,5-\mathrm{T}[(2,4,5-$ trichlorophenoxy) acetic acid], used for mesquite suppression from the 1950's to 1980's (Fisher et al. 1959, Jacoby and Meadors 1983).

Numerous studies have estimated herbage production following chemical treatment of mesquite, but few have monitored production more than 2 or 3 years following treatment (Scifres and Polk 1974, Scifres et al. 1977, Dahl et al. 1978, Bedunah and Sosebee 1984, Heitschmidt and Dowhower 1991, Warren et al. 1996, Laxson et al. 1997). In addition, an understanding of individual species or species functional group responses to treatments both beneath mesquite canopies and in interstitial spaces between mesquite is key to developing ecological and economic models that accurately predict landscape responses to mesquite treatments (Brock et al. 1978, McDaniel et al. 1982).

Upon visiting a research site in north Texas in 1997 that had been used to evaluate efficacy of mesquite herbicides in the 1970s and 1980s (Jacoby et al. 1981, 1990), it was discovered that most of the plots were still intact and well-marked. We concluded there existed a rare opportunity to measure long-term effects of some of these herbicide treatments on grass yield responses under a similar soil, climate and livestock management regime. Moreover, in both the 1970's and 1980's experimental applications, there existed treatments that typically yielded a "top- kill" effect (i.e., high canopy reduction, moderate-to-high top-kill and low rootkill), and others that yielded high root-kill (high canopy reduction and whole plant mortality but not necessarily high top-kill because of the high root-kill rate). Thus, there existed an opportunity to empirically evaluate the longevity of 2 chemical management options for mesquite, which to date has only been assessed through modeling (Teague et al. 2001).

Our objectives were to (1) measure the long-term effects of "top-killing" or "rootkilling" herbicides for mesquite control by quantifying mesquite regrowth and grass yield in areas treated 10 or 20 years earlier, and (2) identify grass species functional groups and associated micro-site areas (interstitial spaces vs. mesquite subcanopy) that are most sensitive to longterm changes in mesquite cover resulting from prior treatment. We hypothesized that warm-season grasses would be more sensitive than cool-season grasses to changes in mesquite cover because peak growth of warm-season grasses occurs when mesquite is in full foliage (Ansley et al. 1992) while peak growth of cool-season grasses usually occurs before mesquite leaf expansion is complete.

\section{Methods and Materials}

\section{Study Site Description}

The study site is located on a private ranch $24 \mathrm{~km}$ southwest of Vernon, Texas (335' $3^{\prime}$., $99^{\circ} 21^{\prime}$ W.; elevation $380 \mathrm{~m}$ ), in the northern Rolling Plains ecological area of Texas. Mean annual precipitation is $665 \mathrm{~mm}$, with peak rainfall bi-modally distributed in May and October. Mean annual air temperature is $17^{\circ} \mathrm{C}$ (NOAA 1999). Soils are fine, mixed, thermic Typic Paleustolls of the Tillman series, $0-1 \%$ slope, which are alluvial clay loams to $4 \mathrm{~m}$ depth, underlain by Permian sandstone/shale parent material (Koos et al. 1962). Vegetation is dominated by a woody overstory of honey mesquite. Graminoid species include a mixture of cool-season $\left(C_{3}\right)$ and warm-season $\left(C_{4}\right)$ grasses. Primary cool-season grass species are the annual grass, Japanese brome (Bromus japonicus Thunb ex. Murray), and the perennial mid-grasses Texas wintergrass (Nasella leucotricha [Trin. and Rupr.] Barkworth). Primary warm-season grasses are perennial short-grass buffalograss (Buchloe dactyloides [Nutt.] Engelm.), and mid-grasses silver bluestem (Bothriochloa laguroides [DC.] Herter. Subspp. torreyana [Steud.]), meadow dropseed (Sporobolus compositus [Poir.] Merr.), sideoats grama (Bouteloua curtipendula [Michx.] Torr.), and vinemesquite (Panicum obtusum HBK). A continuous livestock (cattle) grazing regime has been in place for at least 50 years at a moderate stocking rate of 10-15 ha $A U Y^{-1}$.

\section{Study Site Treatment History}

The study site was originally established in 1977 to evaluate mesquite responses to aerially-applied herbicides (Jacoby and Meadors 1981). Herbicide treatments were arranged in 26 plots in each of 3 rows (78 plots total), with each plot 3.4 ha ( $84 \mathrm{~m} \mathrm{x}$ $400 \mathrm{~m}$ ). Total area of the site is $262 \mathrm{ha}$ $(1200 \times 2184 \mathrm{~m})$. In 1965 , the entire area was commercially treated for mesquite control with 2,4,5-T that reduced canopies of most of the trees and stimulated basal regrowth. By 1977, most mesquite consisted of 12-year-old regrowth plants. Experimental herbicide treatments were applied in a randomized pattern on 36 plots (12 per row) in 1977 and 30 additional plots in 1979. Of these 66 plots, 32 were treated again with aerially-applied herbicides in 1987 or 1988 , following 8 to 11 years of regrowth. The other 34 plots remained untreated after 1977 or 1979. Thus, both the 1970s and 1980s treatments were applied to regrowth mesquite of about the same age. Of the 12 plots that remained untreated following the commercial 2,4,5-T spray in 1965,10 were sprayed in 1981 (and not considered for this study) and 2 remained untreated after 1965. Thus, all plots used for the current study had been randomly located within a common experimental grid.

Herbicide treatments were applied using fixed-wing aircraft in late June or early July. Total spray volume was 18.7 liters $\mathrm{ha}^{-1}$ for the 1977 and 1979 treatments and 37.4 liters ha $^{-1}$ for the 1987 and 1988 treatments. Air temperatures, soil temperatures, and wind speeds were between $23-32^{\circ} \mathrm{C}, 23-29^{\circ} \mathrm{C}$, and $3-16 \mathrm{kmph}$, respectively, at the time of application (Jacoby et al. 1981, Jacoby and Meadors 1983, and Jacoby et al. 1990). Mesquite trees were 2-3 m tall and canopy cover was between 20 and $50 \%$ in all plots.

The initial evaluation of herbicide effects on mesquite was conducted 2 years following each treatment by randomly selecting 80-120 trees along each of 2 transect lines in each plot and recording percent canopy reduction, top-kill and root-kill (data from Jacoby et al. 1981, 1990 , Jacoby and Meadors 1983, and unpublished data on file in Vernon). Top- 
kill is defined in this paper as mesquite with complete mortality of original stems but having basal regrowth. Root-kill refers to trees that are completely dead. Canopy reduction is the percent reduction of foliage on original stems averaged over all plants (partially top-killed, top-killed and root-killed). Thus, if a tree had one branch with foliage on it and the rest of the stems dead, it would not be counted as topkilled.

\section{Treatments for Current Study}

In 1998, we identified 5 treatments to be used for the grass response study. These were: (1) top-killing herbicide applied 10 or 11 years earlier (T10), (2) top-killing herbicide applied 19 or 21 years earlier (T20), (3) root-killing herbicide applied 10 or 11 years earlier (R10), (4) root-killing herbicide applied 19 or 21 years earlier (R20), and (5) untreated control with > 30-year-old regrowth (C30). Top-killing treatments included plots treated with either triclopyr at $0.56 \mathrm{~kg} \mathrm{ha}^{-1}$ or 2,4,5-T at $0.56 \mathrm{~kg} \mathrm{ha}^{-1}$. Both treatments yield functionally similar mesquite responses in terms of percent top-kill and root-kill (Jacoby and Meadors 1983). Root-killing treatments included plots treated either with a 1:1 mixture of clopyralid + triclopyr at $0.28 \mathrm{~kg} \mathrm{ha}^{-1}$ each, or a $1: 1 \mathrm{mix}$ ture of clopyralid $+2,4,5-\mathrm{T}$ at $0.28 \mathrm{~kg} \mathrm{ha}^{-1}$ each, or clopyralid alone at $0.56 \mathrm{~kg} \mathrm{ha}^{-1}$. Mesquite responses to these 3 root-killing treatments were also functionally similar (unpublished observation). The "untreated" control included regrowth mesquite that had been treated commercially in 1965. Over the entire treatment grid of 78 plots, 18 met the conditions of the 5 treatments described above, although number of plots treatment ${ }^{-1}$ was unequal ( 3 for $\mathrm{T} 10,4$ for T20, 4 for R10, 5 for R20 and 2 for $\mathrm{C} 30$ ).

The 2-year evaluation of the plots used for the current study indicated that canopy reduction was $>86 \%$ in all treatments, percent top-kill was greater in the top-kill $(33-49 \%)$ than the root-kill (16-31\%) treatments, and percent root-kill was greater in the root-kill than the top-kill treatments (Table 1). Canopy reduction was higher than top-kill in all treatments because many plants had small portions of foliage remaining on original stems and were not counted as top-killed, even though most of the original stems had been killed. For reasons unknown, rootkill was greater in the R20 than the R10 treatment. Herbaceous responses were not measured during this evaluation.

Table 1. Original canopy reduction, top-kill and root-kill of each treatment when evaluated 2 years after herbicide application. Means are followed by \pm standard error.

\begin{tabular}{|c|c|c|c|c|c|}
\hline $\begin{array}{l}\text { Trt ID } \\
\text { in } \\
1998\end{array}$ & Chemical Treatment & $\begin{array}{c}\text { Year } \\
\text { Sprayed }\end{array}$ & $\begin{array}{l}\text { Canopy } \\
\text { Reduction }\end{array}$ & Top-kill & Root-kill \\
\hline T20 & 0.56 triclopyr or $0.562,4,5-\mathrm{T}$ & $\begin{array}{l}1977 \text { or } \\
1979\end{array}$ & $90 \pm 2$ & $33 \pm 1$ & $5 \pm 1$ \\
\hline T10 & 0.56 triclopyr or $0.562,4,5-\mathrm{T}$ & $\begin{array}{l}1987 \text { or } \\
1988\end{array}$ & $88 \pm 3$ & $49 \pm 14$ & $2 \pm 1$ \\
\hline R20 & $\begin{array}{l}0.56 \text { clopyralid or } \\
0.28 \text { clopyralid }+0.28 \text { triclopyr }\end{array}$ & $\begin{array}{l}1977 \text { or } \\
1979\end{array}$ & $89 \pm 3$ & $16 \pm 5$ & $69 \pm 3$ \\
\hline R10 & $\begin{array}{l}0.56 \text { clopyralid or } \\
0.28 \text { clopyralid }+0.28 \text { triclopyr }\end{array}$ & $\begin{array}{l}1987 \text { or } \\
1988\end{array}$ & $87 \pm 5$ & $31 \pm 6$ & $37 \pm 2$ \\
\hline $\mathrm{C} 30$ & None & --- & 0 & 0 & 0 \\
\hline
\end{tabular}

Replications were 4, 3, 5, 4 and 2 for $\mathrm{T} 20, \mathrm{~T} 10, \mathrm{R} 20, \mathrm{R} 10$ and $\mathrm{C} 30$, respectively.

\section{Mesquite and Grass Responses, 1998-2000}

To measure long-term mesquite and grass responses in 1998-2000, 25 sample areas (each 0.4 ha or $50 \times 80 \mathrm{~m}$ ) were randomly located in the 18 large plots with 5 sample areas allocated to each of the 5 treatments (T20, T10, R20, R10, C30). In most cases, a single 0.4-ha sample area was located within a larger plot. However, in 2 plots in the T10 treatment and 1 plot in each of the T20, R10, and C30 treatments, 2 sample areas were randomly located at opposite ends of the $84 \times 400 \mathrm{~m}$ rectangle. Three sample areas were randomly located in the second C30 plot. These areas were identified as treatment replicates after homogeneity of variance tests showed no clustering grass responses within a plot.

Mesquite population characteristics were measured in 1998. Two, 60-m line transects were established in each 0.4 ha sample area to determine mesquite cover using line intercept (Canfield 1941), and mesquite density using point-centered quarter (PCQ) method at $10 \mathrm{~m}$ intervals (Cook and Stubbendieck 1986). Tree height was measured on each of the 4 individuals at each PCQ point.

Grass yields were measured in 1998, 1999 and 2000. Five micro-site patches were located in each 0.4-ha replicate and were protected from livestock grazing with a 1- x 2-m cage made of welded wire panel. Cages were necessary because grazing pressure from cattle was unusually high due to drought conditions. The 5 micro-site patches represented a combination of grass functional group and microsite location relative to mesquite: (1) coolseason mid-grasses (CSM) in interstitial spaces between mesquite (CSM-I), and (2) beneath mesquite canopies (CSM-C), (3) warm-season short-grasses (WSS) in interstitial spaces (WSS-I), and (4) beneath mesquite canopies (WSS-C), and (5) warm-season mid-grasses (WSM) in interstitial spaces (WSM-I). We were unable to find a sufficient number of WSM patches to sample beneath mesquite canopies. The CSM functional group included only Texas wintergrass and WSS included only buffalograss. The WSM group included silver bluestem, vinemesquite, sideoats grama or meadow dropseed because there was an insufficient number of patches of any one of these species in all sample areas. However, silver bluestem was used in at least 3 of the 5 replicates in each treatment. We defined a "patch" as an area where foliage cover of the target functional group was at least $80 \%$ of the total herbaceous cover and at least $30 \%$ of a 2 to $3-\mathrm{m}^{2}$ area. Within each grass functional group and micro-site location (FGL), numerous patches that met these conditions were first located and, from among this population, patches used for sampling were randomly selected.

Sampled FGL patches were first mowed to 2-cm (stubble) height in February each year $(1998,1999,2000)$ to remove previous year's growth, then caged to exclude grazing. Within each cage, 2 separate 0.25 $\mathrm{m}^{2}$ quadrats were harvested for current year's above-ground biomass, one at an earlier period and the other at a later period during the time of the growing season when peak yield might typically occur for each functional group. The CSM patches were harvested in late-May and mid-July, and WSM and WSS patches were harvested in mid-July and early October (Heitschmidt and Dowhower 1991). Yield values from the 2 sample dates were averaged to estimate peak yield in each year for each functional group. A total of 250 perennial grass quadrats were sampled each year $(5$ herbicide treatments $x 5$ replications treatment ${ }^{-1} \times 5$ FGLs replication ${ }^{-1} \times$ 2 quadrats $\mathrm{FGL}^{-1}$ ). Yield of a fourth func- 
tional group, cool-season annual grasses (CSA), comprised mainly of Japanese brome, was estimated by clipping species in this group within the CSM patches during the May sample period. Because growth of CSA grasses ceased in May each year, this functional group was not sampled in July. All yield data were multiplied by 4 prior to analysis and are expressed as $\mathrm{g} \mathrm{m}^{-2}$.

\section{Statistical Analyses}

Because all herbicide plots were initially established at random in the same experimental area and because grass micro-sites within each herbicide plot were selected at random, mesquite and grass responses were viewed as falling within a randomized statistical design. The authors recognize that in any long-term study there may exist incompatibilities between the original and the current experimental design but every effort was made to collect data in as objective a manner as possible given the constraints of the original design. For objective 1 , mesquite responses in 1998 were analyzed using a 1-way analysis of variance (AOV) with herbicide treatment as the main effect and 5 replications per treatment.

For analysis of grass yields, annual peak yields of 7 FGLs (WSM-I, CSM-I, CSMC, WSS-I, WSS-C, CSA-I and CSA-C) were analyzed separately using a repeated measures $\mathrm{AOV}$ with herbicide treatment and replication as main plots and year $(1998,1999,2000)$ as subplot (SAS 1988). The replicate within treatment mean square was used as the error term in testing effects of treatment, and the pooled error tested effects of year and treatment $\mathrm{x}$ year interaction. Further analysis was conducted within each year if a significant interaction occurred (Freund and Littell 1981). Mean separations were conducted using a protected LSD at $\mathrm{P} \leq 0.05$. Percentage data were subjected to arcsin transformation prior to analysis. Polynomial and logistic regression analyses were performed between mesquite percent cover and yields of each FGL.

\section{Results}

\section{Precipitation}

During the 24-year period from the first herbicide spray treatments in 1977 through 2000 , precipitation was above normal 11 years and below normal 13 years (Fig. 1). During the period of herbaceous production measurement (1998-2000), the site experienced 3 consecutive below normal years that had not occurred since

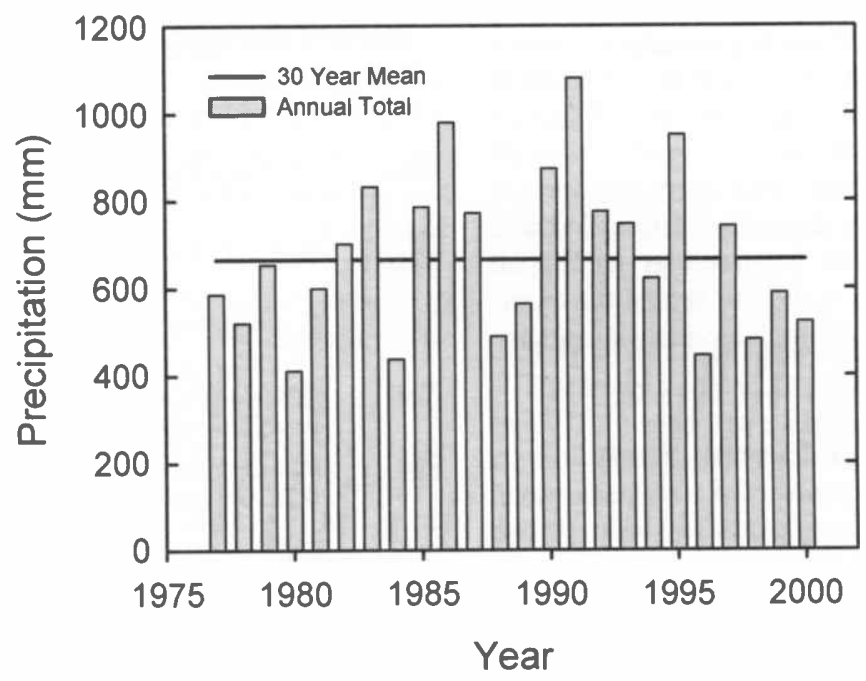

Fig. 1. Annual precipitation at the research site from 1977-2000 (bars). Line represents 30year annual mean.

1977-1981. During 1998-2000, the most extended and extreme periods of drought occurred during the growing seasons of each year, thus exacerbating drought effects (Fig. 2). For example, during the 1998 growing season (April-October), every month experienced below normal precipitation. In 1999, rainfall was near normal in spring, but well below normal from July to October. In 2000, rainfall was below average from April to September after a precipitation pulse in March. Growing season (April-October) precipitation was 102, 336, and $171 \mathrm{~mm}$ in 1998, 1999 and 2000 , respectively. These amounts were 24,78 , and $40 \%$, respectively, of the normal (30year mean) growing season amount of 430 $\mathrm{mm}$.

\section{Mesquite Responses, 1998}

By 1998, mesquite canopy cover was significantly greater in the C30 and T20 treatments than the R20 and R 10 treatments (Fig. 3). Similar to canopy cover, mesquite height and canopy diameter were greatest in the C30 and T20 treatments and lowest in the root-kill treatments. There was no significant difference in mesquite plant density among treatments, although the root-kill treatments showed a trend of having higher density than the other treatments.

\section{Grass Yield Responses, 1998-2000}

Significant treatment $\mathrm{x}$ year interactions existed for all functional group-locations (FGLs). Therefore, means are displayed for each FGL in each year (Figs. 4-7). Peak yield of warm-season mid-grasses in interstitial spaces (WSM-I) was greater in the R20 and/or R10 treatments than the
C30, T20 and T10 treatments in each year (Fig. 4). Greater variation in 1999 data limited statistical significance but clear trends remained.

Cool-season mid-grasses in interstitial spaces (CSM-I) exhibited trends similar to WSM-I grasses in that the root-kill treatments tended to have the greatest yields and treatments with greatest mesquite cover (C30, T20, and T10) had the lowest yields (Fig. 5). Yield of CSM-I was significantly greater in the R20 than the C30 treatment in each year. In general, the magnitude of differences between the root-kill and the other treatments was not as great as with WSM-I grasses. The variation among replicates was lower and therefore numerous significant differences among treatments occurred. For both WSM and CSM grasses there was a trend that yields were greater in the R20 than the R10 treatment. This was probably the result of greater root-kill in the $\mathrm{R} 20$ than the R10 treatment (Table 1).

Warm-season short-grass (i.e., buffalograss) yields varied among treatments and years (Fig. 6). In 1998, WSS-I and WSS-C followed a pattern similar to WSM and CSM responses with greatest yields in the root-kill treatments. However, an opposite trend was found for WSS-C in 2000 (and to a lesser degree in 1999) in that lowest yields were in the treatments with the lowest mesquite cover (T10, R20, R10).

Cool-season annual grass (CSA) yields were highly variable among years with yields in 1999 near $200 \mathrm{~g} \mathrm{~m}^{-2}$ in most treatments (levels similar to WSM-I in the R10 and R20 treatments), while yields were $<65 \mathrm{~g} \mathrm{~m}^{-2}$ in all treatments in 1998 and 2000 (Fig. 7). There was no consistent 


\section{Discussion}
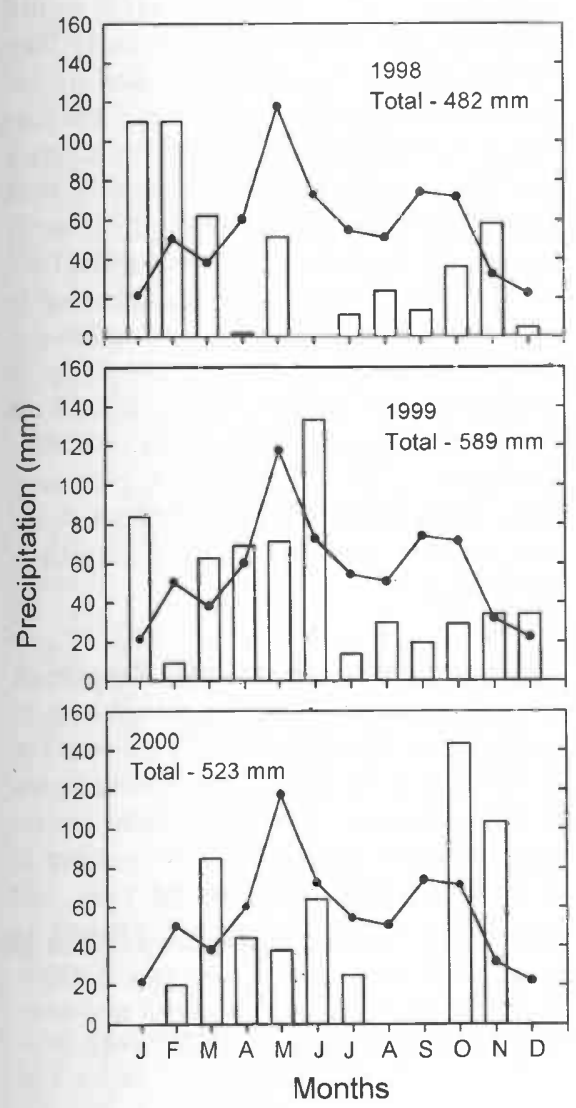

Fig. 2. Monthly precipitation at the research site from 1998-2000 (bars). Line represents 30 -yr monthly means.

pattern of CSA yields with respect to response to mesquite treatments and, in 3 of the 6 panels in Fig. 7, there was no significant difference among treatments.

Regression of mesquite cover and peak yield of WSM-I from all 3 years indicated that there was an inverse sigmoidal relationship in which WSM-I yields maintained high levels at mesquite cover from 0 to $25 \%$ but between cover of $25-40 \%$, WSM-I yields dropped drastically (Fig. 8). There was a quadratic relationship between CSM-I and mesquite cover in which yields were stable at low mesquite cover but declined at an increasing rate with increasing mesquite cover. The relationship between CSM-C and cover was similar (data not shown). There was no relation between mesquite cover and WSS or CSA yields.

\section{Mesquite Responses}

By 1998, mesquite cover was 36 and $47 \%$ in the T10 and T20 treatments, respectively (Fig. 3). If we assume that cover was initially reduced by these topkilling treatments to $<10 \%$, this suggests that cover increased at a rate of 2.6 to 3.1 percentage units per year in the T10, and 1.9 to 2.1 percentage units per year in the T20 treatments. In the root-kill treatments, cover increased from near zero to 12 and $24 \%$ in the R10 and R20 treatments, respectively, or about 1.2 percentage units per year. The rate of cover increase following the root-kill treatments is comparable to that found by Ansley et al. (2001). The data indicate clearly that rate of increase in mesquite cover is greater following top-killing treatments. Post-treatment increases in cover following root-killing treatments are likely to be slower because most of the increase in cover must occur through recruitment and growth of new seedlings (Ansley et al. 2001).

While not significant at $\mathrm{P}<0.05$, mesquite plant density was slightly greater in the root-kill treatments, although we expected density to be lower in these treatments because of the higher initial mortality. There is no internal fencing in the pasture, so cattle and wildlife were free to move across herbicide treatments. The increased herbaceous yields following mesquite rootkilling treatments likely attracted cattle and increased their residence time and rate of fecal deposition. Cattle may have increased mesquite recruitment in these plots by depositing mesquite seeds through their feces (Brown and Archer 1987, Kramp et al. 1998). Lower mesquite height and canopy diameter in the root-kill treatments in 1998 suggests that most mesquite were recruited as new seedlings following herbicide treatments in the 1970 's or 1980's. Competition from existing mature mesquite in the $\mathrm{C} 30$ treatment probably limited recruitment of new seedlings. The top-kill treatments were free from mesquite competition for a few years but as regrowth of top-killed and partially top-killed mesquite grew larger, competition against new seedling recruitment probably increased.

\section{Grass Yield Responses}

Warm-season perennial mid-grasses (WSM) appeared to be most sensitive to changes in mesquite cover. Sensitivity of this functional group was probably related
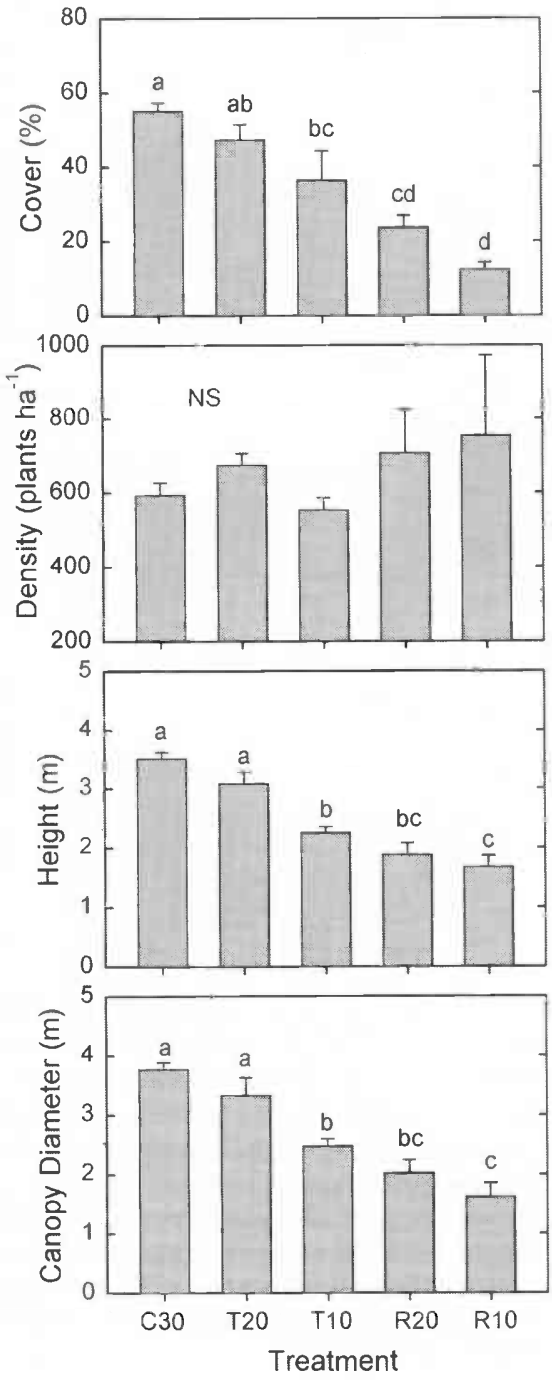

Fig. 3. Mesquite population characteristics in 1998 in response to mesquite treatments. C30 $=$ control, mesquite $>\mathbf{3 0}$ years old, T20 = top-kill herbicide applied 20 years earlier, T10 $=$ top-kill herbicide applied 10 years earlier, $\mathbf{R 2 0}$ = root-kill herbicide applied 20 years earlier, $R 10=$ root-kill herbicide applied 10 years earlier. Means with similar letters are not significantly different at $P<0.05$ (NS $=$ no differences). Vertical bars are 1 s.e.

to the time of peak productivity that coincides with the time mesquite canopy foliage is usually at maximum cover (Heitschmidt and Dowhower 1991, Ansley et al. 1992).

Cool-season mid-grasses (CSM) were sensitive to increases in mesquite cover, but not to the degree that WSM grasses were. The data support our hypothesis that cool-season grasses are less affected by mesquite cover than are warm-season grasses. In our region, peak growth of Texas wintergrass usually occurs in April 


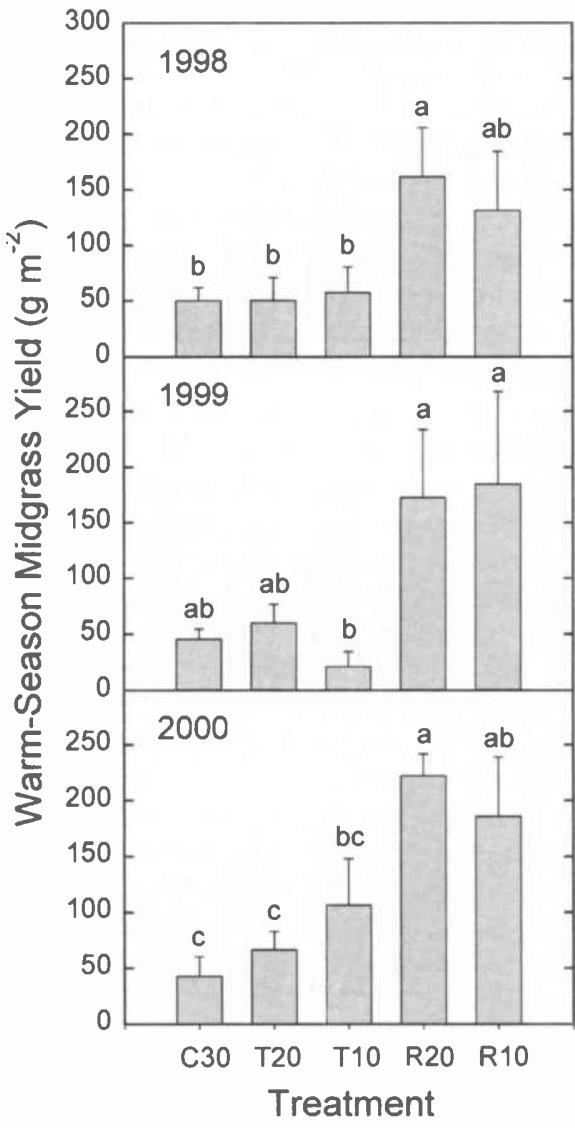

Fig. 4. Peak yield of warm-season mid-grasses in interstitial spaces between mesquite in response to mesquite treatments. Treatment code same as Figure 3. Means with similar letters within each year are not significantly different at $\mathbf{P}<\mathbf{0 . 0 5}$. Vertical bars are 1 S.E.

and early May just prior to mesquite bud burst and foliage expansion. This would explain why CSM was not as sensitive to changes in mesquite cover as was WSM. In 1999, high rainfall in June (Fig. 2) and a relatively cool summer allowed Texas wintergrass to attain peak yields by the July rather than the late-May sample date. However, this did not appear to change the pattern of CSM response to treatments found in the 2 other years (Fig. 5).

The logistic relationship between mesquite cover and WSM-I yield and the quadratic relationship between cover and CSM-I or CSM-C yield suggests that growth of these functional groups is not restricted by the presence of mesquite at low cover. Several studies support our findings and suggest that light densities of mesquite or related woody plants either do not decrease or, in some cases, enhance herbaceous production (Scifres et al. 1982, Weltzin and Coughenour 1990, East and Felker 1993). Other studies have found a negative exponential relationship between woody cover (or density) and herbaceous production in which greatest gains in production occur between 0 and $10 \%$ woody cover (Walker et al. 1972, 1986). Data from Fig. 8 indicates there were 2 "plateaus" of yield for warm-season midgrasses: a higher level at mesquite cover $<25 \%$, and a much lower level at cover $>$ $40 \%$. These plateaus were connected by a precipitous decline within a narrow range (i.e., between 25 and $40 \%$ ) of mesquite cover. While the slope of this decline is probably not as steep as our data indicates, it does suggest a critical range of mesquite cover that when attained, can shift herbage yield rapidly to a much lower potential. This supports the "state-and-transition" theory of community thresholds and suggests herbage responses to increasing mesquite cover may not be a gradual process.

The other warm-season grass functional group, WSS, was much less affected by changes in mesquite cover than was WSM or CSM. Buffalograss is a drought-tolerant species and typically increases in mixed grass stands that become degraded through

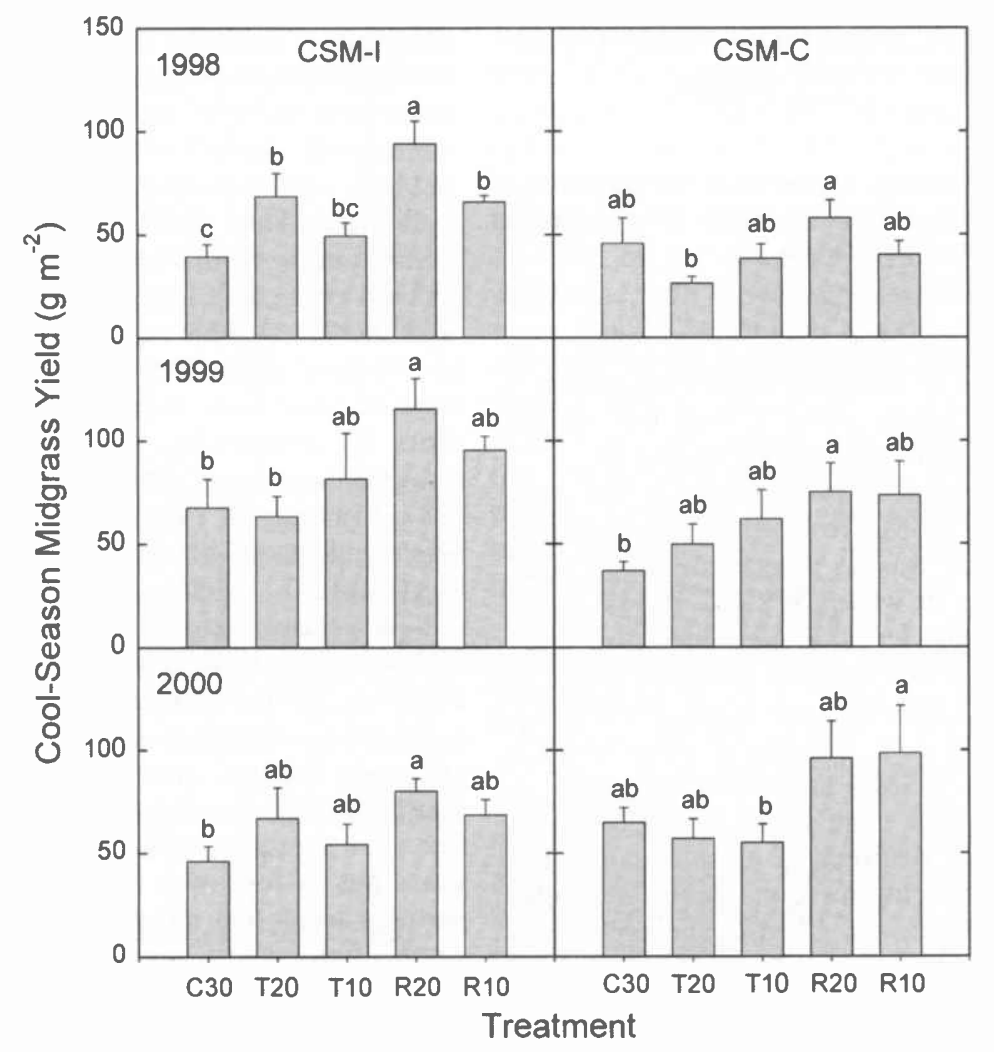

Fig. 5. Peak yield of cool-season mid-grasses in interstitial spaces (CSM-I) and beneath mesquite canopies (CSM-C) in response to mesquite treatments. Treatment code same as Figure 3. Means with similar letters within each year are not significantly different at $\mathbf{P}<$ 0.05. Vertical bars are 1 S.E. over-grazing and mesquite encroachment (Heitschmidt et al. 1986). Thus, it is not surprising that WSS grasses would respond to treatments differently than WSM grasses. Trends in the data are too mixed from year to year to draw clear conclusions but it is apparent that buffalograss can withstand shading from mesquite even in treatments with the highest mesquite cover. As drought progressed from 1999 to 2000 , buffalograss yields appeared to increase in all treatments and micro-site locations except those beneath mesquite canopies in treatments (T10, R20, R10) that had smaller-sized mesquite and lower mesquite cover. These WSS-C plots may have been invaded by mid-grasses (CSM and (WSM) and this may explain their reduced yield.

\section{Cool-Season Annual Grass Responses}

The growth and ecological impacts of cool-season annual grasses were found to be an important part of the overall herbaceous understory dynamic. These grasses typically germinate from November to February, depending on the year, and complete most vegetative growth in 


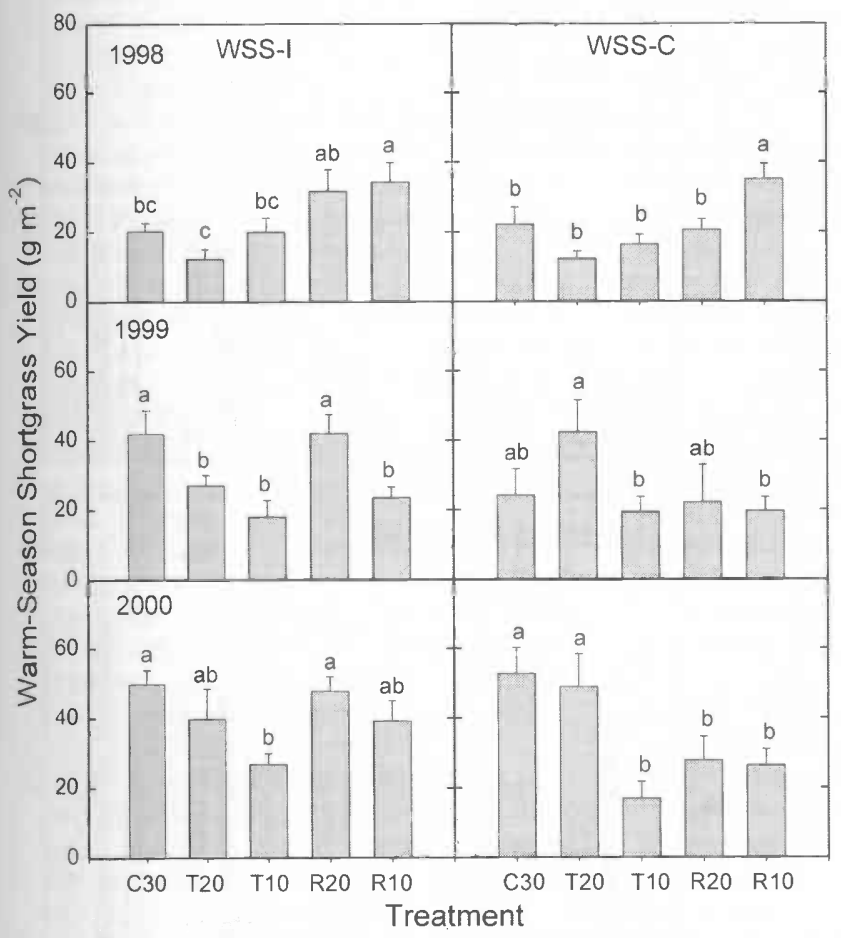

Fig. 6. Peak yield of warm-season short-grasses in interstitial spaces (WSS-I) and beneath mesquite canopies (WSS-C) in response to mesquite treatments. Treatment code same as Figure 3. Means with similar letters within each year are not significantly different at $\mathbf{P}<0.05$. Vertical bars are 1 S.E.

February and March (personal observation). The plants set iseed in April and are dormant by mid-May. As was shown in this study, production is highly variable from year to year. High CSA yield in 1999 was the result of several factors. Low perennial grass production in 1998 due to drought coupled with livestock grazing created an abundance of open ground, thus facilitating annual grass seed germination and establishment. Above normal moisture in November 1998 and January 1999 stimulated germination, and above normal moisture in March and April 1999 sustained growth (Fig. 2). The CSA yields in this study appeared to be unaffected by differences in mesquite cover.

The impact of CSA growth can be seen in warm-season perennial grass yields. Even though growing season (April to October) precipitation was much greater in 1999 than 2000 (336 vs. $171 \mathrm{~mm}$ ), yields of WSM-I, WSS-I and WSS-C grasses were slightly greater in most treatments in 2000 than in 1999 (Figs. 4 and 6). Abundant CSA growth in 1999 may have limited growth of WSM and WSS grasses. During spring, annual grasses utilize soil moisture that may limit warm-season perennial grass growth in April or May

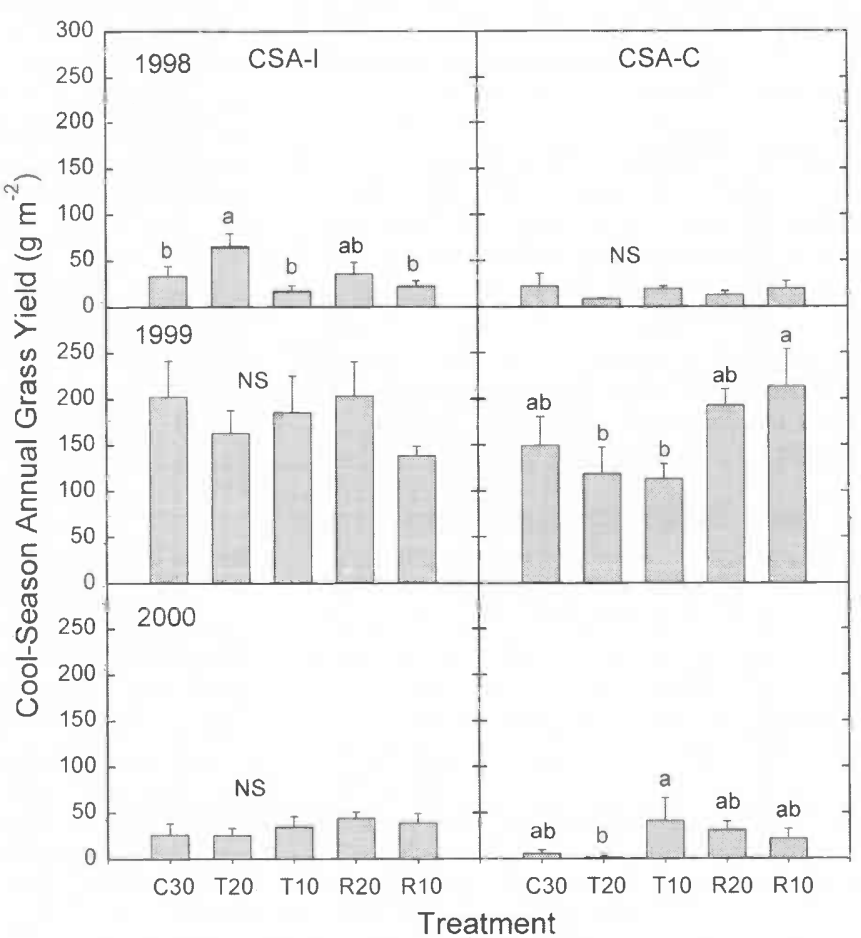

Fig. 7. Peak yield of cool-season annual grasses in interstitial spaces (CSA-I) and beneath mesquite canopies (CSA-C) in response to mesquite treatments. Treatment code same as Figure 3. Means with similar letters within each year are not significantly different at $\mathrm{P}<0.05$ (NS = no differences). Vertical bars are $1 \mathrm{~S} . \mathrm{E}$.
(Whisenant 1989). In addition, shade caused by standing dead annual grass in June and July may inhibit light penetration to leaves of warm-season perennial grasses growing beneath the annual grass canopies, thus limiting photosynthesis. The high standing mass of annual grasses in the spring of 1999 likely physically inhibited warm-season perennial grass growth during the summer of 1999 , even though precipitation was above normal in June 1999 and CSA grasses were dormant (Fig. 2). Height of annual grasses (most of which were Japanese brome) was 0.5 to $0.7 \mathrm{~m}$ in 1999, which is taller than all WSS and most WSM grasses in the region.

\section{Relating to Landscape-Level Responses}

To bring the micro-site values into a management context and to illustrate the combined effects of mesquite encroachment and drought on overall grass yields, yield values of each functional group were scaled to the landscape level. For this exercise, we assumed equal distribution among functional groups within each micro-site location ( $25 \%$ each for WSM, CSM, WSS, and CSA in interstitial and $33 \%$ each for CSM, WSS and CSA in subcanopies), then multiplied these weighted yield values by the percent land area that was either sub-canopy or interstitial space. Scaling was done at the replicate level.

In the 3 drought years, peak yield of perennial grasses was $<800 \mathrm{~kg} \mathrm{ha}^{-1}$ in all treatments (Fig. 9). Normal yields for this region are $1800-2500 \mathrm{~kg} \mathrm{ha}^{-1}$ (McDaniel et al. 1982, Teague et al. 2001). Yields in the root-kill treatments $\left(500-800 \mathrm{~kg} \mathrm{ha}^{-1}\right.$ ) were about twice those in the top-kill and control treatments $\left(230-400 \mathrm{~kg} \mathrm{ha}^{-1}\right)$, reflecting the dominant influence of the warm-season mid-grasses in the scaling process. Addition of cool-season annual grasses did not affect total herbage yields much in 1998 and 2000 but greatly increased yields in all treatments in 1999 . Moreover, increases in treatments with high mesquite cover (C30, T20) were greater relative to the 2 other years than were increases in the treatments with lower mesquite cover (R20, R10). Actual composition of each functional group would affect these scaled projections and will be addressed in another paper. 

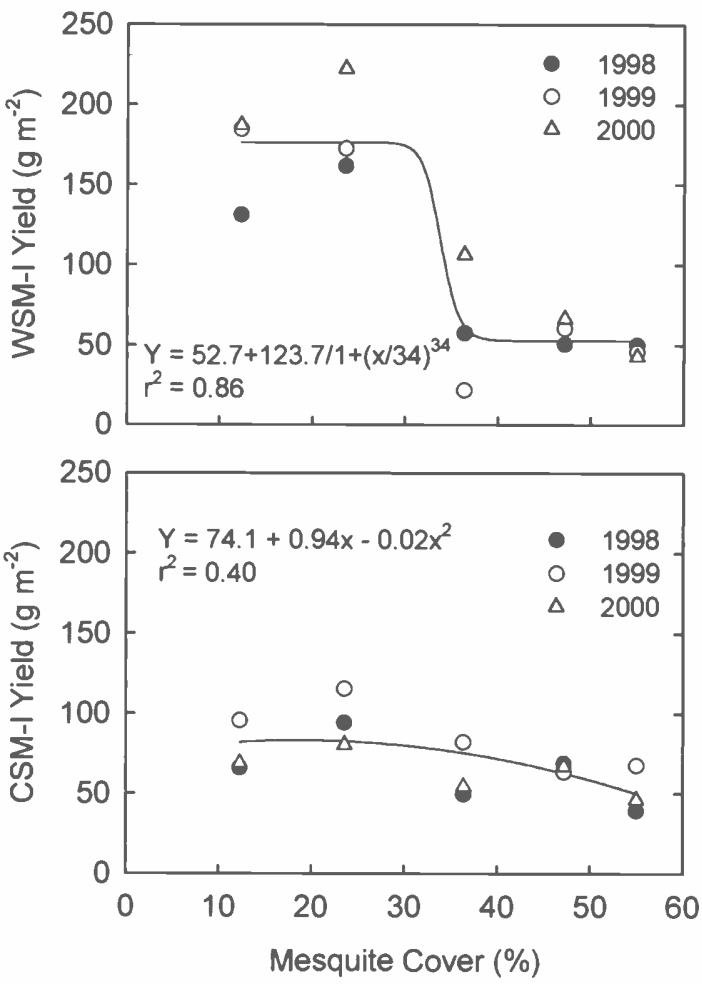

Fig. 8. Regressions between mesquite percent cover measured in 1998 and peak yields of warm-season mid-grasses in interstitial spaces between mesquite (WSM-I) (top) and cool-season midgrasses in interstitial spaces (CSM-I) (bottom) in 1998-2000. Yield data from all 3 years were used to derive regression equations.

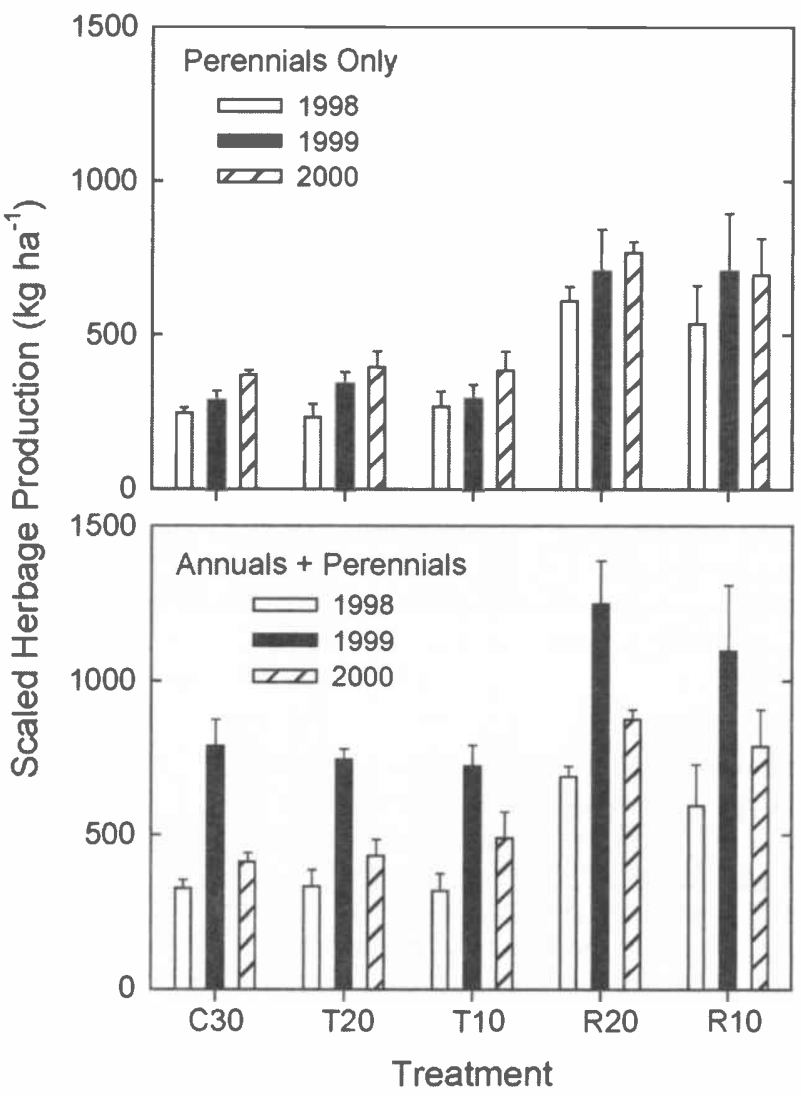

Fig. 9. Yield of perennial (top) and annual + perennial (bottom) grasses, 1998-2000, when scaled to the landscape level in response to historical mesquite treatments. Vertical bars are 1 S.E.

\section{Management Implications}

Rangelands that contain large, dense, multi-stemmed mesquite may require a "reclamation" type treatment to restore grassland productivity (Jacoby et al. 1981, Ansley et al. 2003). Under these circumstances, aerial application of herbicides is viewed as one of the most practical treatments available (Scifres et al. 1985). This study represents a first attempt to quantify long-term herbaceous responses to triclopyr and clopyralid treatments of mesquite.

Results suggest that herbicide treatment life (defined by increased perennial grass yield in response to mesquite treatments) was at least 20 years for the root-killing herbicide, but no longer than 10 years for the top-killing herbicide. Current costs for triclopyr alone at $0.56 \mathrm{~kg} \mathrm{ha}^{-1}$ is about $\$ 37 / \mathrm{ha}$ and the mixture of $0.28 \mathrm{~kg} \mathrm{ha}^{-1}$ clopyralid $+0.28 \mathrm{~kg} \mathrm{ha}^{-1}$ triclopyr is about $\$ 62 \mathrm{ha}^{-1}$. Teague et al. (2001) indicated that effective life of a root-killing treatment that costs $\$ 60-70 \mathrm{ha}^{-1}$ must exceed 20 years, and that a top-killing treatment at $\$ 30-40 \mathrm{ha}^{-1}$ must exceed 10 years to be economically viable. Grass yield data in this study suggest the root-killing herbicide option was economically viable but the top-killing herbicide was not.

Because warm-season mid-grass yield was very sensitive to changes in mesquite cover, we conclude that if this functional group is degraded at the time of mesquite treatment, herbaceous responses to treatment will be compromised. Cool-season mid-grass yields will contribute some to overall increases in herbaceous yield following mesquite treatment, but not to the degree of warm-season mid-grasses. Warm-season short-grass yields, in addition to having much lower potential than warm-season mid-grasses, were at times inversely related to mesquite cover. This functional group would be expected to contribute very little toward increasing herbaceous production following mesquite treatment. Differential responses of grass functional groups may partially explain the inconsistent pattern of herbaceous response to mesquite treatments in other studies (Dahl et al. 1978). It also suggests that response to mesquite treatments may be delayed on degraded areas that are lacking warm-season mid-grasses for a few growing seasons until this functional group can re-establish while mesquite canopies are suppressed.

\section{Literature Cited}

Ansley, R.J., B.A. Kramp, and D.L. Jones. 2003. Converting mesquite thickets to savanna through foliage modification with clopyralid. J. Range Manage. 56:72-80.

Ansley, R.J., X.B. Wu, and B.A. Kramp. 2001. Observation: long-term increases in mesquite canopy cover in a north Texas savanna. J. Range Manage. 54:171-176.

Ansley, R.J., D.L. Price, S.L. Dowhower, and D.H. Carlson. 1992. Seasonal trends in leaf area of honey mesquite trees: determination using image analysis. J. Range Manage. 45: 339-344.

Bedunah, D.J. and R.E. Sosebee. 1984. Forage response of a mesquite-buffalo grass community following range rehabilitation. J. Range Manage. 37:483-487. 
Bovey, R.W. and S.G. Whisenant. 1991. Control of honey mesquite with clopyralid, triclopyr, or clopyralid:triclopyr mixtures. J. Range Manage. 44:52-55.

Brock, J., R.H. Haas, and J.C. Shaver. 1978. Zonation of herbaceous vegetation associated with honey mesquite in northcentral Texas. $\mathrm{p}$ 187-189 In: First Int. Rangeland Congr., Soc. Range Manage., Denver, Colo.

Brown, J.R. and S. Archer. 1987. Woody plant seed dispersal and gap formation in a North American subtropical savanna woodland: the role of domestic herbivores. Vegetatio 73:73-80.

Canfield, R.H. 1941. Application of the line interception method in sampling range vegetation, J. Forest. 39:388-394.

Cook, C.W. and J.E. Stubbendieck. 1986. Range research: basic problems and techniques. Soc. Range Manage., Denver, Colo.

Dahl, B.E., R.E. Sosebee, J.P. Goen, and C.S. Brumley. 1978. Will mesquite control with 2,4,5-T enhance grass production? J. Range Manage. 31:129-131.

East, R.M. and P. Felker. 1993. Forage production and quality of 4 perennial grasses grown under and outside canopies of mature Prosopis glandulosa Torr. var. glandulosa (mesquite). Agroforestry Syst. 22:91-110.

Fisher, C.E., C.H. Meadors, R. Behrenns, E.D. Robison, P.T. Marion, and H.L. Morton. 1959. Control of mesquite on grazing lands. Tex. Agr. Exp. Sta. Bull. 935, College Station, Tex.

Freund, R.J. and R.C. Littell. 1981. SAS for linear models - a guide to the ANOVA and GLM procedures. SAS Institute Inc., Cary, N.C.

Heitschmidt, R.K. and S.L. Dowhower. 1991. Herbage response following control of honey mesquite within single tree lysimeters. J. Range Manage. 44:144-149.

Heitschmidt, R.K., R.D. Schultz, and C.J. Scifres. 1986. Herbaceous biomass dynamics and net primary production following chemical control of honey mesquite. J. Range Manage. 39:67-71.
Jacoby P.W. and C.H. Meadors. 1983. Triclopyr for control of honey mesquite (Prosopis juliflora var. glandulosa). Weed Sci. 31:681-685.

Jacoby P.W., C.H. Meadors, and M.A. Foster. 1981. Control of honey mesquite (Prosopis juliflora var. glandulosa) with 3,6Dichloropicolinic acid. Weed Sci. 29: 376-378.

Jacoby P.W., R.J. Ansley, C.H. Meadors, and C.J. Cuomo. 1990. Control of honey mesquite with herbicides: influence of stem number. J. Range Manage. 43:36-38.

Koos, W.M., J.C. Williams, and M.L. Dixon. 1962. Soil survey of Wilbarger County, Texas. USDA-SCS, Soil Survey Series 1959 , Number 18, Fort Worth, Tex.

Kramp, B.A., R.J. Ansley, and T.R. Tunnell. 1998. Survival of mesquite seedlings emerging from cattle and wildlife feces in a semiarid grassland. Southwest. Nat. 43:300-312.

Laxson, J.D., W.H. Schacht, and M.K. Owens. 1997. Above-ground biomass yields at different densities of honey mesquite. J. Range Manage. 50:550-554.

McDaniel, K.C., J.H. Brock, and R.H. Haas. 1982. Changes in vegetation and grazing capacity following honey mesquite control. J. Range Manage. 35: 551-557.

McGinty, A., J.F. Cadenhead, W. Hamilton, W.C. Hanselka, D.N. Ueckert, and S.G. Whisenant. 2000. Chemical weed and brush control suggestions for rangeland. Texas Agr. Ext. Serv. Bull. B-1466.

NOAA. 1999. Climatological data annual summary, Vol 104. National Oceanic and Atmospheric Administration, Asheville, N.C.

SAS 1988. SAS/STAT User's Guide Version 6.03, SAS Inst. Inc., Cary, N.C.

Scifres, C.J. and D.B. Polk. Jr. 1974. Vegetation response following spraying of light infestation of honey mesquite. J. Range Manage. 27:462-465.

Scifres, C.J., G.P. Durham, and J.L. Mutz. 1977. Range forage production and consumption following aerial spraying of mixed brush. Weed Sci. 25:48-54.
Scifres, C.J., J.L. Mutz, R.E. Whitson, and D.L. Drawe. 1982. Interrelationships of huisache canopy cover with range forage on the coastal prairie. J. Range Manage. 35: 558-562.

Scifries, C.J., W.T. Hamilton, J.R. Conner, J.W. Stuth, J.M. Inglis, T.G. Welch, G.A. Rasmussen, and R.P. Smith. 1985. Integrated brush management systems for south Texas: development and implementation. Texas Agr. Exp. Sta. Bull. 1493.

Teague, W.R., R.J. Ansley, U.P. Kreuter, J.M. McGrann, and W.E. Pinchak. 2001. Economics of managing mesquite in north Texas: a sensitivity analysis. J. Range Manage. 54: 553-560.

VanTassell, L.W. and J.R. Conner. 1986. An economic analysis of brush control practices and grazing systems in the Rolling Plains of Texas. Texas Agr. Exp. Sta. MP-1619.

Walker, J., R.M. Moore, and J.A. Robertson. 1972. Herbage response to tree and shrub thinning in Eucalyptus populnea shrub woodlands. Aust. J. Agr. Res. 23: 405-410.

Walker, J., J.A. Robertson, and L.K. Penridge. 1986. Herbage response to tree thinning in a Eucalyptus crebra woodland. Aust. J. Ecol. 11: 135-140.

Warren, A., J. Holechek, and M. Cardenas. 1996. Honey mesquite influences on Chihuahuan desert vegetation. J. Range Manage. 49:46-52.

Weltzin, J.F. and M.B. Coughenour. 1990. Savanna tree influence on understory vegetation and soil nutrients in northwestern Kenya. J. Veg. Sci. 1:325-334.

Whisenant, S.G. 1989. Modeling Japanese brome population dynamics. p 176-185 In: Proc. Western Soc. Weed Sci. Ann. Meeting, Honolulu, Hawaii. 